\title{
NOTE
}

\section{Susceptibility of juvenile Atlantic cod Gadus morhua to viral haemorrhagic septicaemia virus isolated from wild-caught Atlantic cod}

\author{
M. Snow*, C. O. Cunningham, I. R. Bricknell \\ FRS Marine Laboratory, PO Box 101, Victoria Road, Aberdeen AB11 9DB, United Kingdom
}

\begin{abstract}
A European strain of viral haemorrhagic septicaemia virus (VHSV) isolated from wild-caught cod Gadus morhua (H16/7/95) was shown to cause clinical disease and mortality in excess of $80 \%$ in juvenile Atlantic cod when administered by the intra-peritoneal (i.p.) route. No virus was recovered from cod cohabiting with experimentally infected fish at a ratio of $1: 1$, and no VHSV-associated mortality was demonstrated following inmersion infection. External signs of disease in cod were the presence of exophthalmia and ascites. Virus was identified as VHSV by enzyme-linked immunosorbent assay (ELISA) and was recovered from both brain and organ pools (kidney, liver and spleen) of $100 \%$ of i.p. infected cod mortalities. Virus was also detected using an indirect immunofluorescence test on tissue imprints of kidney, liver, spleen and brain taken from moribund fish. The fact that cod were not susceptible to VHSV following waterborne exposure raises important questions surrounding the propagation, maintenance and impact of a naturally occurring reservoir of virus in the marine environment.
\end{abstract}

KEY WORDS: Viral haemorrhagic septicaemia virus - VHSV . Novirhabdovirus $\cdot \mathrm{Cod}$

The novirhabdovirus viral haemorrhagic septicaemia virus (VHSV) is the etiological agent of a disease which is responsible for considerable losses to the European trout farming industry. Although once thought to be confined to rainbow trout Oncorhynchus mykiss in fresh water, VHSV has since been isolated from a number of wild marine fish species caught in European waters including cod Gadus morhua (Jensen et al. 1979, Smail 1995, Mortensen et al. 1999), haddock Melanogrammus aeglefinus (Smail 2000 - in this issue), herring Clupea harengus harengus (Dixon et al. 1997. Mortensen et al. 1999), sprat Sprattus sprattus, whiting Merlangius merlangus (Mortensen et al. 1999) and farmed turbot Scophthalmus maximus (Schlotfeldt et al. 1991, Ross et al. 1994).

\footnotetext{
·E-mail: snowm@marlab.ac.uk
}

The association of European VHSV with wild marine fish has been demonstrated and VHSV epizootics have been recorded in turbot farmed in West Scotland (Ross et al. 1994) and in SW Ireland (McArdle pers. comm.). The identification of a link between isolates causing mortalities in turbot and those recovered from wild fish caught in the North Sea (Stone et al. 1997, Snow et al. 1999) raises important questions concerning the impact of European VHSV on marine fish populations.

The development of aquaculture in the UK, coupled with declining fish stocks, has led to an increased interest in the farming of marine fish species of commercial importance such as cod. Commercially-reared fish will potentially be exposed to any naturally occurring pathogens that are enzootic in the local marine environment, such as VHSV. The recent interest in cod farming, coupled with a lack of commercially available vaccine, has thus rendered the issue of cod susceptibility to VHSV important and worthy of addressing. The current study was initiated to determine the virulence of a European VHSV isolate recovered from wildcaught cod to pathogen-free juvenile cod held under experimental conditions.

Methods. Cell culture and virus propagation: The epithelioma papulosum cyprini (EPC) cell line (Fijan et al. 1983) was used for the isolation, propagation and identification of virus in this study according to previously described methods (Snow \& Smail 1999). The isolate of VHSV used in this study was recovered in 1995 from wild cod caught in the North Sea (H16/7/95; Smail 2000). Stock virus was produced from virus stored following 2 passages on EPC cells.

Prior to intra-peritoneal (i.p.) infection of cod, virus was subjected to an additional in vivo passage in cod. A dose of $1.7 \times 10^{7} \mathrm{TCID}_{50} \mathrm{fish}^{-1}$ was administered to 10 experimental fish by intra-peritoneal injection. A single pool of kidney and spleen tissue was made at Day 3 post-infection, diluted 1:5 in G-MEM-10 and homogenised using a pestle and mortar. Following centrifu- 
gation of the tissue homogenate at $3000 \times g$ for $20 \mathrm{~min}$, the resultant supernatant was stored in aliquots at $-80^{\circ} \mathrm{C}$ and re-titrated following a single freeze-thaw cycle.

Pathogen-free fish: Atlantic cod (mean weight $14.3 \mathrm{~g}$ ) were produced at the Sea Fish Industry Authority Marine Farming Unit, Ardtoe, Argyll, Scotland, UK. Rainbow trout (mean weight $9.1 \mathrm{~g}$ ) were produced at the FRS Experimental Fish Production Unit, Aultbea, Wester-Ross, Scotland and used as the reference susceptible fish species (de Kinkelin et al. 1979, de Kinkelin \& Castric 1982). Prior to infection, 10 fish were sacrificed and the organs (kidney, liver and spleen) of individual fish removed and screened for the presence of VHSV, infectious pancreatic necrosis virus (IPNV) and infectious haematopoietic necrosis virus (IHNV) as previously described (Snow \& Smail 1999).

Challenge of cod with VHSV isolate H16/7/95: Cod and rainbow trout testing virus negative were held in $30 \mathrm{l}$ aquaria supplied with $11 \mathrm{~min}^{-1}$ sea water at $10^{\circ} \mathrm{C}$ and allowed to acclimate for $7 \mathrm{~d}$. All tanks received aeration for the duration of the study.

Intra-peritoneal and cohabitation infection: Cod and rainbow trout were stocked in each of 4 tanks at a density of 20 fish per tank, and in a 5th tank at a density of 10 fish per tank. Ten individuals were removed from each of the tanks stocked at a density of 20 fish per tank, marked, and injected i.p. with $1.99 \times 10^{8}$ $\mathrm{TCID}_{50}$ virus in a volume of $100 \mu \mathrm{l}$. Cod and trout were marked by clipping the dorsal and adipose fins, respectively. Experimentally infected fish were then returned to the original tank to cohabit at a ratio of 1 VHSV infected fish : 1 uninfected fish. Negative control animals were fin clipped and sham-injected i.p. with $100 \mu \mathrm{l}$ phosphate buffered saline (PBS) and returned to the remaining 5 th tank.

Immersion infection: Cod and trout were held in each of 4 tanks at a density of 20 fish per tank. Triplicate tanks of both cod and rainbow trout were challenged in $10 \mathrm{l}$ with a dose of $1 \times 10^{5} \mathrm{TCID}_{50} \mathrm{ml}^{-1}$ virus administered in a volume of $10 \mathrm{ml}$. A 4 th group of cod and trout were challenged with an equivalent volume of GMEM-10 to serve as negative controls. All fish were exposed to virus for a period of $4 \mathrm{~h}$, after which the flow to individual tanks was restored.

Mortality was recorded for the duration of both experimental infections (64 d). Brain and organs (kidney, liver, spleen) from individual dead fish and those surviving at the end of the challenge were sampled separately and stored at $-80^{\circ} \mathrm{C}$ for virological examination.

Virus recovery and identification: Brain and organ pools (kidney, liver, spleen) were diluted 1:10 in GMEM-10 (w/v), processed and inoculated onto EPC cells for virus recovery as previously described (Snow
\& Smail 1999). Virus was identified using a commercially available enzyme-linked immunosorbent assay (ELISA) according to the manufacturers' instructions (Test-Line Ltd). ELISA was performed directly on organ homogenates and on second passage EPC supernatants stored as above.

Immunofluorescence: Tissue imprints of kidney, liver, spleen and brain from moribund cod were made by gently pressing the freshly-cut surface of organs onto a clean microscope slide. Imprints were fixed by immersion in 1:1 methanol:acetone $(\mathrm{v} / \mathrm{v})$ for $3 \mathrm{~min}$ and stored at $4^{\circ} \mathrm{C}$. Positive control slides were prepared by infecting EPC cells in 16-well tissue-culture chamber slides (Nunc) with VHSV at a multiplicity of infection $>1$. Infected and uninfected cultures were fixed as detailed above at $24 \mathrm{~h}$ post-infection. Slides were airdried and blocked with $5 \%(\mathrm{w} / \mathrm{v})$ skimmed milk solution and covered with monoclonal antibody IP5311 against VHSV N protein (Lorenzen et al. 1988) (MAb) at a 1:50 dilution for $60 \mathrm{~min}$. Slides were then washed 3 times in PBS with $0.1 \%$ Tween-20. Imprints were stained with FITC labelled goat anti-mouse conjugate (Sigma 1:1000 dilution) for $60 \mathrm{~min}$ at room temperature and then washed. Finally the imprints were covered in propidium iodide in PBS with $0.1 \%$ Tween-20 (0.001 $\mathrm{mg} \mathrm{ml}^{-1}$ ) and incubated for $2 \mathrm{~min}$ at room temperature, then washed in PBS/0.1\% Tween-20, drained and mouted in polyvinyl alcohol mounting medium (Falk et al. 1998). Slides were stored at $4^{\circ} \mathrm{C}$ prior to examination on a Leica DMLB microscope using an epifluorescent attachment and 13 filter at $\times 40$ magnification.

Results. Infection of cod with VHSV isolate H16/ 7/95: No viruses were detected in either the cod or rainbow trout prior to infection. Virus was recovered following a single round of in vivo passage in cod with a titre of $1.99 \times 10^{9} \mathrm{TCID}_{50} \mathrm{ml}^{-1}$.

Data from all infection experiments are summarised in Table 1.

Intra-peritoneal and cohabitation infection: Mortality in i.p. infected cod commenced at $3 \mathrm{~d}$ post-infection and reached a mean final cumulative mortality of $85 \%$ by $19 \mathrm{~d}$ post-infection. Two mortalities were recorded from the cohabiting cod at 30 and $39 \mathrm{~d}$ post-infection. A single mortality occurred in the negative control fish at $39 \mathrm{~d}$ post-infection.

Mortality in i.p. infected rainbow trout commenced at $6 \mathrm{~d}$ post-infection, reaching a mean final cumulative mortality of $10 \%$ at $49 \mathrm{~d}$ post-infection. Two mortalities were recorded from cohabiting fish at 44 and $45 \mathrm{~d}$ postinfection. No mortalities occurred in negative control rainbow trout for the duration of the challenge

Moribund cod did not generally exhibit the classical features described for VHS in rainbow trout (WoIf 1988), although limited exophthalmia and ascites were noted (data not shown). 
Table 1. VHSV infecting Gadus morhua and Oncorhynchus mykiss. Summary of results obtained from the challenge of cod and rainbow trout with VHSV isolate H16/7/95. Mort.: no. of mortalities; Surv.: no. of survivors; cpe: cytopathic effects

\begin{tabular}{|c|c|c|c|c|c|c|c|c|c|c|}
\hline \multirow{3}{*}{$\frac{}{\operatorname{Cod}}$} & \multirow{2}{*}{\multicolumn{2}{|c|}{$\begin{array}{l}\text { i.p. } \\
\text { Mort. Surv. }\end{array}$}} & \multicolumn{2}{|c|}{ Cohabitation } & \multicolumn{2}{|c|}{ Immersion } & \multicolumn{2}{|c|}{ i.p. control } & \multicolumn{2}{|c|}{ Immersion control } \\
\hline & & & & Surv. & Mort. & Surv. & Mort. & Surv. & Mort. & Surv. \\
\hline & & & & & & & & & & \\
\hline Total/Total no. of fish & $34 / 40$ & $6 / 40$ & $2 / 40$ & $38 / 40$ & $11 / 60$ & $49 / 60$ & $1 / 10$ & $9 / 10$ & $1 / 20$ & $19 / 20$ \\
\hline $\begin{array}{l}\text { Proportion of organ pools tested } \\
\text { resulting in tissue culture cpe }\end{array}$ & $\begin{array}{l}34 / 34 \\
(100 \%)\end{array}$ & $0 / 6$ & $0 / 2$ & $0 / 19$ & $0 / 11$ & $0 / 49$ & $0 / 1$ & $0 / 9$ & $0 / 1$ & $0 / 19$ \\
\hline $\begin{array}{l}\text { Proportion of organ pool cpe } \\
\text { tested positive by ELISA }\end{array}$ & $17 / 17$ & - & - & - & - & - & - & - & - & - \\
\hline $\begin{array}{l}\text { Proportion of brain pools tested } \\
\text { resulting in tissue culture cpe }\end{array}$ & $\begin{array}{c}34 / 34 \\
(100 \%)\end{array}$ & $0 / 6$ & $0 / 2$ & $0 / 19$ & $0 / 11$ & $0 / 49$ & $0 / 1$ & $0 / 9$ & $0 / 1$ & $0 / 19$ \\
\hline $\begin{array}{l}\text { Proportion of organ pool cpe } \\
\text { tested positive by ELISA }\end{array}$ & $17 / 17$ & - & - & -- & - & - & - & - & - & - \\
\hline Rainbow trout & & & & & & & & & & \\
\hline Total/Total no. of fish & $4 / 40$ & $36 / 40$ & $2 / 40$ & $38 / 40$ & $2 / 60$ & $58 / 60$ & $0 / 10$ & $10 / 10$ & $1 / 20$ & $19 / 20$ \\
\hline $\begin{array}{l}\text { Proportion of organ pools tested } \\
\text { resulting in tissue culture cpe }\end{array}$ & $\begin{array}{c}4 / 4 \\
(100 \%)\end{array}$ & $0 / 18$ & $0 / 2$ & $0 / 19$ & $0 / 1$ & $0 / 58$ & - & $0 / 5$ & $0 / 1$ & $0 / 10$ \\
\hline $\begin{array}{l}\text { Proportion of brain pools tested } \\
\text { resulting in tissue culture cpe }\end{array}$ & $4 / 4$ & - & - & - & - & - & - & -- & - & - \\
\hline $\begin{array}{l}\text { Proportion of organ pool cpe } \\
\text { tested positive by ELISA }\end{array}$ & $\begin{array}{c}4 / 4 \\
(100 \%)\end{array}$ & - & - & - & - & - & - & - & - & - \\
\hline
\end{tabular}

Virus was recovered from both the brain and visceral organs of all the i.p. injected cod mortalities as determined by production of cytopathic effect on EPC cells (Table 1), and identified as VHSV by testing of $50 \%$ of the resultant tissue culture supernatants by ELISA. No virus was detected from any of the organ pools of i.p. infected fish or cohabiting cod surviving at the end of the experimental infection period.

VHSV was recovered from a sub-cutaneous lesion from a single i.p. infected cod surviving at the end of the experimental infection period but not from the organs of the same fish. In addition, VHS virus was recovered from haemorrhaged fin tissue sampled from a mortality resulting from i.p. infection.

Virus was recovered from organs of each of the 4 rainbow trout mortalities following i.p. infection and was identified as VHSV by ELISA. No virus was recovered from 2 control mortalities in cohabiting fish. Similarly, no virus was detected in any of the i.p. or cohabiting rainbow trout surviving at the end of the experimental infection period.

Immersion infection: Mortality in immersioninfected cod commenced at $6 \mathrm{~d}$ post-infection and ranged from 0 to $40 \%$ in individual tank replicates. No mortality was recorded after $40 \mathrm{~d}$ post-infection when the mean cumulative mortality had reached $18.3 \%$. A single mortality was recorded in control fish at $20 \mathrm{~d}$ post-infection.

Mortality in immersion-infected rainbow trout commenced at $22 \mathrm{~d}$ post-infection, although a total of only 2 mortalities occurred by $50 \mathrm{~d}$ post-infection. A single mortality occurred in control fish at $6 \mathrm{~d}$ postinfection.

No virus was recovered from any of the 11 mortalities which occurred following infection of cod via the immersion route, from immersion-infected survivors or from any of the control immersion-infected cod.

No virus was recovered from the single rainbow trout mortality following immersion infection or from control immersion-infected rainbow trout.

Immunofluorescence: VHSV-infected cell culture positive controls produced a uniform fluorescence while no fluorescence was present in negative control cell cultures or organ imprints from uninfected cod. Cell-associated fluorescence was detected in imprints of kidney, liver and spleen made from 5 of 6 moribund cod and from brain imprints sampled following i.p. infection, indicating the presence of VHSV (data not shown). Cell-associated fluorescence was also identified in imprints taken from the brain of one of these fish following i.p. infection (data not shown). No fluorescence was identified in imprints from 6 cod sampled following cohabitation with i.p. infected cod.

Discussion. Juvenile cod were highly susceptible to VHSV isolate H16/7/95 following i.p. infection. However, transmission of virus via cohabitation with i.p. infected individuals was not demonstrated in this study, and no VHSV-associated mortality was identified following immersion exposure with isolate H16/ 7/95. Only limited VHSV-associated mortality was demonstrated in rainbow trout following i.p. infection, while no VHSV-associated mortality occurred follow- 
ing virus exposure by cohabitation or immersion routes. Rainbow trout were not susceptible to isolate H16/7/95, confirming previous findings that European marine isolates of VHSV are generally of low virulence to salmonids ( $N$. Olesen pers. comm.). However, since no other species have been identified for which isolate H16/7/95 is pathogenic, rainbow trout were selected as the most likely susceptible control species.

VHSV was found in $100 \%$ of both organ and brain tissues recovered from cod mortalities resulting from i.p. infection with isolate H16/7/95, thus fulfilling Rivers' postulates for viral disease (Rivers 1937). The identification of VHSV from the brain of infected cod by culture and IFAT supports recent findings that virus was recoverable from the brain of turbot following experimental infection with an isolate from farmed turbot (860/94; Ross et al. 1994, Snow \& Smail 1999). Since the brain offers the potential for virus to persist and escape immuno-detection, this may have significant implications in the maintenance of viral reservoirs in wild fish.

VHSV was recovered from haemorrhagic fin tissue from a single cod which died following i.p. infection. Whether this virus was present as a result of systemic infection, or as a result of secondary infection due to waterborne exposure from fish that were shedding virus remains unknown. Virus associated with a single sub-cutaneous lesion was also detected in a single cod surviving i.p. infection. An association of VHSV with cod exhibiting the 'ulcus syndrome' was described as early as 1979 (Jensen et al. 1979). Since then, North American VHSV has been recovered in association with skin ulcers in Pacific cod Gadus macrocephalus (Meyers et al. 1992), Pacific herring (Meyers et al. 1994) and Atlantic cod (Smail 1995). Whether the presence of VHSV was incidental to these skin lesions or played a role in their etiology remains to be fully determined.

Although high levels of mortality were recorded following i.p. infection of cod with isolate $\mathrm{H} 16 / 7 / 95$, viral challenge via the cohabitation or immersion routes better reflects natural VHSV infection, which occurs by the horizontal transmission of waterborne virus (Wolf 1988). In this study, VHSV was not recovered from cod cohabited with i.p. injected fish. The recent demonstration of a model for infection of turbot with isolate $860 / 94$ by cohabitation and immersion provides strong evidence for VHSV of marine origin to be horizontally transmitted in sea water (Snow \& Smail 1999). Although the degree to which cod excrete virus remains unknown, the fact that cod were shown to be largely resistant to immersion infection suggests that cod may be naturally resistant to waterborne infection with isolate $\mathrm{H} 16 / 7 / 95$. Epidermal tissues have been reported to exert an important role in facilitating or denying the entry of virus in susceptible or resistant fish respectively (Yamamoto et al. 1990, Dorson \& Torhy 1993). Whether such mechanisms are responsible for the contrasting findings regarding the susceptibility of turbot and cod to different VHSV isolates following waterborne infection remains to be determined.

Field observations have indicated that in many cases VHS virus has been recovered from the internal organs of wild-caught Atlantic cod (Mortensen et al. 1999). The mechanism by which virus gains entry to wild fish remains unknown, but if cod are resistant via waterborne challenge, virus may gain entry via other routes. Of particular interest is virus uptake via the ingestion of VHSV-infected prey fish, a method of VHSV uptake which has been demonstrated in northern pike Esox lucius (Ahne 1980).

While the susceptibility of Pacific herring to a VHSV isolate recovered from North America has been demonstrated (Kocan et al. 1997), this is the first study to investigate the susceptibility of a marine fish species to an isolate of VHSV from wild fish recovered from the European marine environment.

The findings that cod were not susceptible to VHSV isolate $\mathrm{H} 16 / 7 / 95$ via waterborne infection may indicate that VHSV may not pose a serious threat to future cod production. However, since the role of VHSV in wild fish stocks remains poorly understood, more work is required to evaluate the epizootiological role of this important fish pathogen in both cod and other wild fish species.

Acknowledgements. The authors are grateful to Kevin McKenzie for his excellent electron microscopy support and to Dr Niels Lorenzen for kindly providing the monoclonal antibody used in this study. The authors are indebted to Robin Shields of the Seafish Industry Authority for providing the cod used in this study.

\section{LITERATURE CITED}

Ahne W (1980) Experimentelle Egtved Virus Infektion beim Hecht (Esox lucius L.). Tierarztl Umsch 35:25-229

de Kinkelin P, Castric $J$ (1982) An experimental study of the susceptibility of Atlantic salmon fry, Salmo salar L., to viral haemorrhagic septicaemia. J Fish Dis 5:57-65

Dixon PF, Feist S, Kehoe E, Parry L, Stone DM, Way K (1997) Isolation of viral haemorrhagic septicaemia virus from Atlantic herring Clupea harengus from the English Channel. Dis Aquat Org 30:81-89

Dorson M, Torchy C (1993) Viral haemorrhagic septicaemia virus replication in external tissue excised from rainbow trout, Oncorhynchus mykiss (Walbaum), and hybrids of different susceptibilities. J Fish Dis 16:403-408

Falk K, Namork E Dannevig BH (1998) Characterisation and applications of a monoclonal antibody against infectious salmon anaemia virus. Dis Aquat Org 34:77-85

Fijan N, Sulimanovic D, Bearzotti M, Muzinic D. Zwillenberg LO, Chilmonczyk S, Vautherot JF, de Kinkelin P (1983) Some properties of the epithelioma papulosum cyprini 
(EPC) cell line from carp (Cyprinus carpio). Ann Inst Pasteur Virol 134:207-220

Jensen NJ, Bloch B, Larsen JL (1979) The ulcus syndrome in cod (Gadus morhua) III. A preliminary virological report. Nord Vetmed 31:436-442

Kocan R, Bradley M, Elder N, Meyers $T$, Batts B, Winton J (1997) North American strain of viral hemorrhagic septicaemia virus is highly pathogenic for laboratory-reared Pacific herring. J Aquat Anim Health 9:279-290

Lorenzen N, Olesen NJ, Vestergard Jørgensen PE (1988) Production and characterization of monoclonal antibodies to four Egtved virus structural proteins. Dis Aquat Org 4: $35-42$

Meyers TR, Sullivan J, Emmenegger E, Follet J, Short S, Batts WN, Winton JR (1992) Identification of viral hemorrhagic septicaemia virus isolated from Pacific cod Gadus macrocephalus in Prince William Sound, Alaska, USA. Dis Aquat Org 12:167-175

Meyers TR, Short S, Lipson K, Batts WN, Winton JR, Wilcock J, Brown E (1994) Association of viral hemorrhagic septicaemia virus with epizootic hemorrhages of the skin in Pacific herring Clupea harengus pallasi from Prince William Sound and Kodiak Island, Alaska, USA. Dis Aquat Org 19:27-37

Mortensen HF, Heur OE, Lorenzen $\mathrm{N}$, Otte $\mathrm{L}$, Olesen $\mathrm{NJ}$ (1999) Isolation of viral haemorrhagic septicaemia virus from wild marine fish species in the Baltic sea, Kattegat, Skagerrak and the North Sea. Virus Res 63:95-106

Rivers TM (1937) Viruses and Koch's postulates. J Bacteriol 33:1-12

Ross K, McCarthy U, Huntly PJ, Wood BP, Stuart D, Rough EI, Smail DA, Bruno DW (1994) An outbreak of viral haemor-

Editorial responsibility: Jo-Ann Leong,

Corvallis, Oregon, USA rhagic septicaemia (VHS) in turbot (Scophthalmus maximus) in Scotland. Bull Eur Assoc Fish Pathol 14:213

Schlotfeldt HJ, Ahne W, Jørgensen PEV, Glende W (1991) Occurrence of viral haemorrhagic septicaemia in turbot (Scophthalmus maximus) - a natural outbreak. Bull Eur Assoc Fish Pathol 11:105-107

Smail DA. (2000) Isolation and identification of viral haemorrhagic septicaemia (VHS) viruses from cod Gadus morhua with the ulcus syndrome and from haddock Aeglefinus melanogramus having skin haemorrhages in the North Sea. Dis Aquat Org 41:231-235

Snow M, Smail DA (1999) Experimental susceptibility of turbot Scophthalmus maximus to viral haemorrhagic septicaemia virus isolated from cultivated turbot. Dis Aquat Org 38:163-168

Snow M, Cunningham CO, Melvin WT, Kurath G (1999) Analysis of the nucleoprotein gene identifies distinct lineages of viral haemorrhagic septicaemia virus within the European marine environment. Virus Res 63:35-44

Stone D M, Way K, Dixon PF (1997) Nucleotide sequence of the glycoprotein gene of viral haemorrhagic septicaemia (VHS) viruses from different geographical areas: a link between VHS in farmed fish species and viruses isolated from North Sea cod (Gadus morhua L.). J Gen Virol 78: 1319-1326

Wolf K (1988) Fish viruses and fish viral diseases. Cornell University Press, Ithaca

Yamamoto T, Batts WN, Arakawa CK, Winton JR (1990) Multiplication of infectious haematopoietic necrosis virus in rainbow trout following immersion infection: whole body assay and immunochemistry. J Aquat Anim Health 2: $271-280$

Submitted: October 12, 1999; Accepted: March 28, 2000

Proofs received from author(s): June 13, 2000 